BULLETIN Bulletin hispanique

HISPANIQUE Université Michel de Montaigne Bordeaux

111-1 | 2009

Varia

\title{
Las «cacerías secretas» de una reescritura musical
}

Sobre dos «mudanzas» de Trakl en Esta luz Poesía reunida (1947-2004) de Antonio Gamoneda

Laurence Breysse-Chanet

\section{OpenEdition}

Journals

Édition électronique

URL : http://journals.openedition.org/bulletinhispanique/933

DOI : 10.4000/bulletinhispanique.933

ISSN : 1775-3821

Éditeur

Presses universitaires de Bordeaux

Édition imprimée

Date de publication : 1 juin 2009

Pagination : 195-217

ISBN : 978-2-86781-586-7

ISSN : 0007-4640

Référence électronique

Laurence Breysse-Chanet, "Las «cacerías secretas» de una reescritura musical », Bulletin hispanique [En ligne], 111-1 | 2009, mis en ligne le 01 juin 2012, consulté le 01 mai 2019. URL : http://

journals.openedition.org/bulletinhispanique/933; DOI : 10.4000/bulletinhispanique.933 


\title{
Las «cacerías secretas» de una reescritura musical Sobre dos «mudanzas» de Trakl en Esta luz Poesía reunida (1947-2004) de Antonio Gamoneda ${ }^{1}$
}

\author{
Laurence Breysse-Chanet \\ Université de Paris IV - Sorbonne, CRIMIC
}

J'explore ici la traduction par Antonio Gamoneda de deux poèmes de Trakl, qui ferment (ouvrent ?) Esta luz Poesía reunida (1947-2004). Des versions proposées " de façon fort peu généreuse, totalement intéressée ", selon leur auteur : une appropriation, où le lecteur découvre un art poétique.

Exploro aqui la traducción por Antonio Gamoneda de dos poemas de Trakl, que cierran (¿abren?) Esta luz Poesía reunida (1947-2004). Dos versiones hechas "de manera muy poco generosa, totalmente interesada", según su autor : una apropiación en la que el lector descubre un arte poética.

I will here explore Antonio Gamoneda's translation of two poems from Trakl, which close (open?) "Esta luz Poesía reunida (1947-2004)». Translations that are proposed in a "much ungenerous way", according to their author - "motivated by a strong selfinterest” even - : an appropriation in which the reader can discover ars poetica.

Mots-clés : Poésie - Traduction - Gamoneda - Trakl.

1. [Una versión abreviada y parcial de este texto se publica en el Dossier dedicado por la revista Ínsula a Antonio Gamoneda, n 736, invierno 2007-2008, con el título «Una simetría extrańa». Una lectura de "Canción del solitario», mudanza de Trakl en Esta luz Poesía reunida (1947-2004) de Antonio Gamoneda, p. 24-26.]

$B H i$, Tome 111, n 1 - juin 2009 - p. 195 à 217. 
quizá alguna vez yo he sido o voy a ser el vigilante de la nieve

A. G.

E N MUCHas ocasiones, expresó Antonio Gamoneda su desconfianza no tanto de los críticos -a los que escucha y lee con la generosidad y la atención que sabemos- como del mismo poder de explicación del pensamiento discursivo frente al misterio del poema. Según lo dijo al presentar en noviembre de 2006 la antología Silabas negras, "La poesía, yo pienso que no se explica»-añadiendo que desde su punto de vista, hasta "no debe explicarse, porque la poesía no consiste exactamente en la escritura de un pensamiento verdaderamente discursivo, y diría que incluso no consiste en la escritura de un pensamiento reflexivo.» ${ }^{2}$ Así como el yo en Cecilia, podría decir el poema: "Pero también quiero permanecer desconocido en ti.» ${ }^{3}$ Vacila el fundamento de la crítica poética, y aún más cuando pretende acercarse a la obra gamonediana. Se necesita un discurso atento a la derrota de lo más estrictamente racional, abierto hacia un «comercio musical» con lo desconocido, según la expresión de «Recortes y extravíos» ${ }^{4}$.

Pues llevada de una «razón musical», - «hay una música en mí, esto es cierto» dice el yo de Arden las pérdidas (466, 475)-, la voz gamonediana persigue al mismo tiempo su identidad y el momento en que «vienen a la vez suavemente, como una sola sustancia, el pensamiento y su desaparición» (Arden las pérdidas, 475). Una poética si no negativa, por lo menos melancólicamente tensa por la permanente conciencia del no vivir, entre el doble abismo de inexistencia que rodea toda existencia, cuya latencia hace inencontrable el rostro, "realidad múltiple y cambiante» (Descripción de la mentira, 206). En cambio, se identifica en seguida una escritura que fluye ${ }^{5}$

2. Antonio Gamoneda, presentación de Sílabas negras, Madrid, 29 de nov. de 2006 (XV Premio Reina Sofía de Poesía Hispanoamericana, ed. de Amelia Gamoneda y Fernando F. de la Flor, Ediciones Universidad de Salamanca Patrimonio Nacional, 2006).

3. Antonio Gamoneda, Cecilia, Esta luz Poesía reunida (Poesía 1947-2004), epílogo de Miguel Casado, Barcelona, Galaxia Gutenberg/Círculo de lectores, 2004, p. 509. En adelante citaré en el mismo texto las referencias a los poemarios de Esta luz.

4. Id., El cuerpo de los símbolos, Madrid, Huerga y Fierro, 1997, p. 184.

5. Con una precisión sobre el sentido de tal fluidez, que nada tiene que ver con la idea de facilidad: «[...] la palabra "fluye" no me gusta, es decir, se pone en movimiento y yo no puedo decir que mi escritura haya visto su forma de manera instantánea, definitiva y para siempre. Estoy averiguando la fórmula constantemente [...].» (Antonio Gamoneda, «Realidad versus realismo. Entrevista con Antonio Gamoneda», Benito del Pliego y Andrés Fischer, Hispanic Poetry Review, vol. 5, n 2, Texas A\&M University, p. 86. Recogido en El lugar de la reunión. Conversaciones con Antonio Gamoneda, ed. Carmen Palomo, Burgos, Ed. Dossoles, 2007, p. 140). 
en su misma presencia material en la página, en sus «bloques de sentido y de sonido rítmicos»-el poema es «tempestad que se manifiesta musicalmente»-, o en sus largos fraseos ${ }^{6}$. Basta con ver las dos «mudanzas» que concluyen Esta luz, «Canción del solitario» (571-572) y «Sueño y locura» (572), para leerlas como una manifestación más de la escritura de Antonio Gamoneda. En la introducción de su Antología poética, Tomás Sánchez Santiago insiste en que en Mudanzas, se juntan poemas «afectos al poeta Gamoneda y transmutados por él en aquel alarde de evaporización de la autoría hasta dejarlos remojados en las mismas orillas de la personal escritura del poeta» ${ }^{7}$. En Mudanzas, la mención del año 1961 recuerda que la presencia de Nazim Hikmet y de las letras de blues corresponde con la escritura de Blues castellano. En la medida en que la traducción de Herodías de Mallarmé es un trabajo a cuatro manos con Amelia Gamoneda, es más indirecta la relación de esa mudanza con el mundo poético de Esta luz.

En cambio, con su sola disposición tipográfica, se imponen en su evidencia gamonediana las versiones de Trakl de 2003. Traducción a su manera la mudanza, ¿qué traducirá? Si para Antonio Gamoneda explicar un poema es imposible -rehuso que dice mucho sobre su poética-, decidí acercarme a su mundo desde la música de sus límites, camino de la exploración de aquellos dos textos finales, más extraños que extranjeros. Pues en las dos lunas de aquel armario donde nunca se reflejan los poemas originales, van a desatarse los «nudos negros» en la lengua, frente a la propia "penumbra auricular» y sus "ocultas bóvedas» (Libro del frío, 385, 387). Precisamente gracias a la intimidad distante con Trakl, nace una energía enigmática, que ofrece el retrato de una doble reconciliación: la de la escritura española con la armonía trakleana, la del yo consigo mismo.

\section{LA BÚSQUEDA DE UN ESPEJO TRAKLEANO (LA CONTEMPLACIÓN DE CUATRO VERSIONES ESPAÑOLAS HACIA SU REESCRITURA)}

El año 2003 se presenta como nuevo «año de la necesidad» (Descripción de la mentira, 174). Es el año de la reescritura de Sublevación inmóvil, de Exentos I, Exentos II, Descripción de la mentira, Lápidas, para su reunión en

6. El cuerpo de los símbolos, op. cit., p. 188 y 178. Sobre Libro del frío como «relato hablado con música de simetrías», y de modo más general sobre el fraseo gamonediano, cf. Ildefonso Rodríguez, «Las músicas de Gamoneda», Espacio/Espaço escrito, n 23 y 24, Badajoz, 2004, p. 37-44.

7. Tomás Sánchez Santiago, «La armonía de las tormentas», Antonio Gamoneda, Antología poética, selección e introducción de Tomás Sánchez Santiago, Madrid, Alianza Editorial, 2006, p. 32. 
Esta luz. Al mismo tiempo se prosigue la escritura de Arden las pérdidas, Cecilia y Exentos III. Por fin, Antonio Gamoneda publica en diciembre, en la revista Letras Libres «Dos versiones de Georg Trakl» ${ }^{8}$, las que van a rematar Esta luz.

La idea de reescritura, aplicada a la propia obra, es «un derecho que [se] reserva indefinidamente» Antonio Gamoneda, que la menciona varias veces en su reciente entrevista para Quimera. Así, a propósito de Sublevación inmóvil: "A ese libro le he pegado un repaso que lo he dejado temblando.»" Lo reafirmó el poeta en la presentación de Sílabas negras, la reescritura tiene para él un sitio fundamental, dada su concepción de la poesía como «arte de la memoria», que «lleva consigo precisamente en la memoria la temporalización de [su] vida en [su] escritura»:

Esta reescritura se produce no por un afán de pulimentación o de ornamentación y algo así del poema del que se trate, sino porque yo entiendo que el poema no es una piedra perfectamente rígida e inamovible, sino que precisamente porque es una emanación de mi vida y no se trata de ficción ninguna en absoluto, sino que es el poema un organismo viviente.

Igual que la poesía, será "irremediablemente subjetiva» ${ }^{10}$ la reescritura. De aquí el desvanecimiento de la noción de autoría: "Yo me puedo imitar a mí mismo, corregir también a mí mismo, apropiarme de lo otro, con tal de que ciertamente sea capaz de interiorizarlo, de llevarlo a la subjetividad.» La misma fuerza compulsiva lleva a "superponer» poemas propios y versiones ajenas, según un acorde básico de tres notas, que define la mudanza, término musical: “violación”, más o menos rompedora, de un texto anterior mío o ajeno, creación y collage.» ${ }^{11}$ El verdadero guía de la escritura es un anhelo de "vertebración musical»: "Es el dictado musical el que articula la forma», a partir de la "pulsación musical», el "pulso generativo», que existe en el lenguaje poético ${ }^{12}$. Entonces en la celebración de «una amistad dentro de mí

8. Le agradezco a Jordi Doce el haberme dado a conocer esta publicación, «Dos versiones de Georg Trakl», Antonio Gamoneda, Letras libres, diciembre de 2003, p. 46-47.

9. Antonio Gamoneda, Edad (Poesía 1947-1986), ed. Miguel Casado, Madrid, Cátedra, 2000, p. 367. A continuación, «Somos únicamente palabras. Antonio Gamoneda en conversación», Marta Agudo (Ed.), Dossier Claridad sin descanso, Quimera, n 275, oct. 2006, p. 28.

10. Art. cit., p. 27 y 33.

11. «Avisos y explicaciones», Esta luz, op. cit., p. 10.

12. Quimera, art. cit., p. 29; HPR, art. cit., p. 82-83 o El lugar de la reunión, art. cit., p. 136. 
mismo», el reencuentro no será sino musical. La revelación del otro se da por el oído: “¿Quién ha entrado en mis oídos?», pregunta la voz de Descripción de la mentira $(174,220)$, al tiempo que busca su propia identidad reflexiva - «cuando silban las cuerdas depositadas en el alma, silban los números» (203). El retrato del poeta sería un retrato en músico -y así se entiende la honda cercanía de las páginas que Ildefonso Rodríguez, poeta y músico, dedica a la obra de Antonio Gamoneda: «La música es uno de los elementos constitutivos del espacio poético abierto por Gamoneda, se corresponde con el proyecto, hace más firme su múltiple coherencia.» ${ }^{13}$

Es cuando interviene una nota imprevista. Me refiero a la nota que sigue las versiones de Trakl en Letras libres, titulada «Nota del autor». Tal paradójica reivindicación de autoría dice que no se trata de una mera versión, sino de un texto, propiamente dicho. La palabra empleada a continuación subraya que algo importante está en juego: «Para la reescritura de estos fragmentos de Georg Trakl me he servido de las siguientes fuentes en castellano». En la «soledad abierta» ${ }^{14}$ de Antonio Gamoneda, la mudanza es plenamente reescritura. Entonces, ¿por qué y cómo reescribir dos poemas de Trakl?

Proponerle una explicación a la primera pregunta es difícil y poco relevante. Miguel Casado y Fernando Castro Flórez aludieron ya a extrañas semejanzas entre dos peregrinaciones crepusculares -y por cierto suenan a mundo trakleano versículos como «Una rama de espino ha penetrado en mi corazón y sin embargo no he despertado de este sueño" o "Subes hasta un lugar de espinos; tocas el borde del crepúsculo», de Descripción de la mentira (209, 212). En 1996, en una entrevista en la que José Luis Calvo Vidal alude a Saint-John Perse, a Georg Trakl y a René Char, así contesta Antonio Gamoneda sobre los poetas nombrados:

[...] perfectamente elegidos, son obras con las cuales yo acepto una afinidad. Quizá, el caso más ilustrativo pueda ser el siguiente: a mí me decían, «oye, cómo se nota que has frecuentado mucho a Trakl... hay una gran cercanía entre lo que haces y la obra de Trakl, ten cuidado...» Y yo no había leído a Trakl. Lo leí después y dije «es verdad». [... ${ }^{15}$

13. Ildefonso Rodríguez, art. cit., p. 37.

14. «[...] la poesía, al fin y al cabo, se da en soledad, aunque sea una soledad abierta.» (Javier Rodríguez Marcos, «La poesía se escribe desde la perspectiva de la muerte», entrevista a Antonio Gamoneda, Babelia, El País, 23/8/2003, p. 3.)

15. Miguel Casado, «Introducción» a Edad, op. cit., p. 13 y Fernando Castro Flórez, "Manos de tierra», en Antonio Gamoneda, Madrid, Calambur, col. Los solitarios y sus amigos, 1993, p. 35. José Luis Calvo Vidal, "Entrevista a Antonio Gamoneda», Moenia, Lugo, II, 1996, p. 568. 
Alude a «las coloraturas, los impulsos y la sentimentalidad» que están en Trakl y pudo recibir por una vía indirecta. En realidad, poco importan datos objetivos, tal cercanía es un misterio, son afinidades, "la causa única». En Quimera, Antonio Gamoneda tampoco precisa la fecha de su lectura de Trakl, tardía por lo menos ${ }^{16}$. Un encuentro fuera del tiempo, a lo mejor hermanado con el día doloroso de la "reflexión luminosa» de Descripción de la mentira (216). La brusca caída de "Avisos y explicaciones» abre con pudor el horizonte del drama interior compartido, una oscura simetría a la que se puede aludir sólo en el poema: «Nada más tengo que decir.»

Es conocida la intensa admiración de Yeats por la Herodías mallarmeana, que leyó en inglés, antes de decidir irse a París para conocer a Mallarmé. De la admiración de Gamoneda por Trakl, sólo tenemos aquellas dos huellas. Interesada por el enigma de su presencia, hice dos veces unas preguntas a Antonio Gamoneda acerca de ellas. En junio del 2005, me contestó:

[...] debo decirle que mi "collage» de versiones de Trakl se debió a que, sin dudar de la corrección literal de las traducciones, echaba de menos en ellas la condición de poema. Me resultaban únicamente informativas. Yo intenté que estos dos fragmentos alcanzasen, en español, tal condición. No sé si lo logré ${ }^{17}$.

De hecho en «Letras Libres», Antonio Gamoneda alude a sus cuatro «fuentes en castellano", y en Esta luz modula la noción de reescritura, diciendo que ha "contemplado e interpretado» cuatro versiones al castellano, que han sido sus «únicas fuentes». Las referencias, en orden cronológico descendente, son iguales: Angélica Becker, Américo Ferrari, José Luis Reina Palazón y Ángel Sánchez ${ }^{18}$. Ahora bien, las menciones resultan subjetivas, pues la primera

16. Art. cit., p. 30. Creo que se entiende mejor la sentimentalidad trakleana cuando se toma en cuenta la influencia que tuvieron sobre Trakl las traducciones de Rimbaud por Klammer, que suavizó a menudo, o hasta descartó, los versos más ásperos de Rimbaud -sin por eso disminuir la fascinación de Trakl por la temática de Rimbaud y su modo de construir el poema (Véase Rémy Colombat, Rimbaud-Heym-Trakl Essai de description comparée, Berna, Frankfurt, Nueva York, París, Peter Lang, 1987, vol. 2, p. 385-702.)

17. Carta de Antonio Gamoneda del 25-6-2005, que cito agradecida con su autorización.

18. Las cuatro fuentes aludidas por Antonio Gamoneda son las siguientes: Georg Trakl, Cantos de muerte. Antología, selección, traducción y estudio de Angélika Becker, Barcelona, Seix Barral, 2001 (ed. revisada y ampliada); Georg Trakl, Sebastián en sueños, versión de Américo Ferrari, Madrid, Buenos Aires, Valencia, Editorial Pre-Textos, 2001; Georg Trakl, Obras completas, ed. y trad. José Luis Reina Palazón, Madrid, Ed. Trotta, 1a ed. 1994, 2000; Georg Trakl, Poemas, traducción, selección y prólogo de Ángel Sánchez, Madrid, Visor, 1973. Cito en el mismo texto las páginas de las versiones aludidas. 
antología, Cantos de muerte, no incluye los dos poemas seleccionados. ¿La imanará su título, que anuncia una poesía "en la perspectiva de la muerte» ${ }^{19}$, resuelta en canto? Américo Ferrari propone en Sebastián en sueños, de 1995, los dos poemas seleccionados por Antonio Gamoneda, "Canto del apartado en la muerte» (142-145) y "Rodeado por la noche/Ensueño y delirio» (146159). En 1994, José Luis Reina Palazón, en Obras completas, elige como títulos "Canto del retraído» (134) y «Sueño y entenebrecimiento» (135-138). Por fin, en 1973, en Poemas, Ángel Sánchez anuncia las selecciones posteriores de Gamoneda, con los títulos de "Canto del solitario» (115-116) y «Sueño y locura» (117-122). Notamos que las mudanzas quedan desprendidas de su origen, pues en ellas se olvida la referencia al poemario de Trakl. En "Avisos y explicaciones», con tono grave se introduce una presencia, conquistada al final de un itinerario: «Finalmente está Georg Trakl».

Las huellas son pocas, pero son profundas, y redes complejas las vinculan a la misma obra poética. Aludir a la "condición de poema» pone en juego la identidad poética de la reescritura. Pero además se trata de un universo particular, el de Trakl. Hice más preguntas a Antonio Gamoneda sobre posibles momentos de consciente interferencia con su obra, quizá camino de una lectura posesiva. Me respondió en términos de cercanía, comprensión y evidencia, que modulan la primera negación:

No. Salvo que en el 2003 -no recuerdo nada de fechas- las leídas versiones «informativas» me hacían sospechar un texto poemático original del cual, sí, yo me adivinaba cercano. Elegí esos poema y fragmento de Trakl porque, en ellos, la posibilidad de cercanía y comprensión se me hacía más evidente. Ninguna otra razón ${ }^{20}$.

Obvio es decir que no le busco fuentes a la obra. Unas afinidades no explican nada, ni agotan la interpretación. Quiero interrogar una relación tensa entre una distancia máxima («me hacían sospechar»: Antonio Gamoneda no lee el alemán, y se instala en una relación reflexiva dentro de su idioma materno) y una voluntad no sólo de lectura posesiva («Salvo que...»), sino hasta diría de reescritura posesiva ${ }^{21}$. Con la elección de Georg Trakl, entra en las «negras

19. Tal referencia refleja la identidad más honda de la poesía de Antonio Gamoneda. Cf. «Poesía en la perspectiva de la muerte», El cuerpo de los simbolos, op. cit., p. 29.

20. Respuesta de Antonio Gamoneda (carta del 22-3-2007) que me permite publicar.

21. Me refiero al título del artículo de Antonio Gamoneda, "Una lectura posesiva de Jorge Guillén», en Jorge Guillén, el hombre y la obra, Actas, Valladolid, Universidad, 1995, p. 293295. 
entrañas musicales» (Arden las pérdidas, 413) de Antonio Gamoneda un caso extremo de la experiencia subjetiva, pues con el poeta austriaco se afirma la conciencia del papel irreductible de la persona. Como lo explica Rémy Colombat, la singularidad de Trakl se sitúa precisamente en la novedad del tratamiento del componente subjetivo y en la extrema tensión de su discurso lírico $^{22}$. Lo dijo Rilke, los poemas de Trakl excluyen al lector, por cercano que esté:

Ces vues, ces aperçus n'arrivent jusqu'à nous qu'au travers d'une vitre. On en demeure exclu: l'expérience de Trakl est comme faite d'images dans le miroir et emplit tout son espace impénétrable comme l'espace du miroir... ${ }^{23}$.

La transparencia es tanta que el espacio parece inmenso, lleno de secretos inviolables, sin llave ni puerta. Así comenta Marc Petit:

Cet univers en trompe l'ail est toute transparence. Nul n'y pénètre par effraction: l'image se trouble ou se fragmente. Aller vers Trakl, c'est pas à pas le suivre, marcher dans son ombre en sachant qu'on ne le rejoindra jamais.

Aquí está el paradójico desafío de Antonio Gamoneda, «apropiación indebida ${ }^{24}$, en su afán por hermanarse con este universo de transparencia opaca precisamente sin penetrar en él, sin salir de los límites de la propia lengua espańola -quizá desde la imposibilidad donde sin escuchar, se oye: «Ninguna otra razón.»

22. Henry Colombat, "Du rêve romantique au préjugé mallarméen", Austriaca, dic. $1987, n^{\circ} 25$, p. 45 . Trakl no abandona la experiencia del yo sino que la extiende más allá de las normas empíricas. Su lirismo no es impersonal sino que más bien se distingue por la intensidad de la expresión subjetiva. (Cf. Rimbaud-Heym-Trakl, op. cit., p. 685.)

23. Rilke, citado en "Préface», Georg Trakl, Crépuscule et déclin suivi de Sébastien en rêve, pref. de Marc Petit, trad. de Marc Petit y Jean-Claude Schneider, París, NRF Poésie Gallimard, p. 7 y p. 11 para la cita de Marc Petit a continuación.

24. Antonio Gamoneda se refiere de esta manera a su experiencia de «algo que quizá no se pueda llamar traducción sino "mudanza"»: «un término que tomé del gran poeta portugués Helberto Helder quien, cuando dice que traduce poemas escritos en lengua sioux o nauatl, nos engaña de una manera extraordinariamente interesante, dado que él tampoco conoce esas lenguas. En mi caso hago estas versiones de manera muy poco generosa, totalmente interesada. En el fondo, de lo que se trata es de la conversión de la poesía de un extranjero en mi poesía, de una apropiación indebida.» («Antonio Gamoneda, el triunfo de la justicia poética», Amalia Iglesias Serna, Dossier Gamoneda, Minerva, Círculo de Bellas Artes, abril 2007, p. 14.) 


\section{EN LAS «HABITACIONES CÓNCAVAS» DE LA CANCIÓN (LÁPIDAS, 29I)}

Los dos poemas, que flotan en suspensión encima del espacio ya total de Esta luz, son los dos últimos poemas de Sebastián en sueño. El primer poema, "Gesang des Abgeschiedenen», dedicado a Karl Borromaeus Heinrich, fue publicado por Trakl en la revista Der Brenner, el $1^{\circ}$ de abril de 1914. El segundo, publicado el $1^{\circ}$ de febrero de 1914, "Traum und Umnachtung», pertenece al grupo de tres relatos en prosa que Trakl escribió poco antes de su muerte. En el poemario, Trakl decidió simbólicamente invertir el orden cronológico de la composición, anteponiendo el segundo poema, uno de sus cantos más claros, que define la poesía como elección armónica y elección melancólica. El poema de la dramática inarmonía pasa a ocupar el segundo lugar, manifestando a modo de testamento, antes de «Grodek» y los últimos poemas publicados en Der Brenner, la incapacidad definitiva para acallar las fuerzas del mal y la disonancia ${ }^{25}$.

«Gesang des Abgeschiedenen» escenifica una palabra esencial en el lirismo trakleano. Como lo explica Adrien Finck, «Abgeschiedenen» significa apartado de: de la vida, difunto, y del mundo, según el sentido propio del léxico religioso de la tradición del misticismo alemán. Mediante la dedicatoria, en correspondencia con los ensayos publicados por Heinrich en Der Brenner en 1913, la palabra llega a referirse al aislamiento interior, frente a la corrupción de la época, a la que se opone la tentación eremítica. Las traducciones francesas se dividen en dos campos: el de la muerte, el de la soledad. Por una parte, "Chant du défunt» para Henri Stierlin en 1956, "Chant du trépassé» según Marc Petit y Jean-Claude Schneider, mientras los heideggerianos, Beaufret, Bokmeier y Jean-Michel Palmier, proponen "Chant du Dis-Cédé». Por otra, según Adrien Finck, el traductor más cercano sin duda al sentido alemán es Jacques Legrand, quien opta por «Chant de l'Isolé», con i mayúscula para conferirle a la palabra la fuerza de un símbolo. Michèle Finck comparte la misma elección ${ }^{26}$.

¿Cuáles son las elecciones de las versiones españolas contempladas por Antonio Gamoneda? Américo Ferrari es el único en traducir por «Canto del apartado en la muerte». José Luis Palazón propone "Canto del retraído», y Ángel Sánchez «Canto del solitario»-hacia la opción gamonediana de

25. Mi conocimiento de la obra trakleana debe mucho a los trabajos de Michèle Finck, en particular "Poétique comparée de "Génie" de Rimbaud et de "Chant de l'Isolé" de Trakl: Tensions du "projet harmonique"”, en Poésie moderne et musique "Vorrei e non vorrei" Essai de poétique du son, París, Honoré Champion, 2004, p. 76-103.

26. Cf. Adrien Finck, "Chant de l'Isolé», Austriaca, op. cit., p. 117-118. Para la traducción de Michèle Finck, cf. op. cit., p. 80. 
la «Canción del solitario». Ahora bien, Antonio Gamoneda es el único en elegir la palabra «canción». Mana de ella un hilo invisible que la vincula con cuantas canciones aparecen en los poemas, rasgando breve e intensamente el velo de la desesperanza, desde el furor ${ }^{27}$ hasta el fervor. Como un bajo continuo, desde Lápidas, a veces «alas se abren sobre mi frente», y desde la visión trágica, cuya violencia proyecta el drama fuera del yo -«Vi la infección en los jardines ciudadanos...»-, surge sin transición lo incomprensible: "y, sin embargo, fue un día alimentado por la dulzura. Una canción se instala en la lentitud y la distancia habla en la música.» $\mathrm{El}$ «veneno» del recuerdo se deshace en «miel negra», y por la fuerza reconciliadora de la canción, se cumple la cita con la música del recuerdo sosegado, de la melancolía y el silencio: «Una tristeza giratoria acude a la restitución del silencio y las torres arden bajo los pájaros tardíos.» (Lápidas, 272) Elegir como título "Canción del solitario", forma poética que como tal cabe en la memoria, intensifica el alcance del poema de Trakl. Pues es un poema de muchas confluencias. En él se oyen las voces de Hölderlin, el «hermano sagrado», poeta loco que huyó del mundo, sumido en la armonía de su mundo poético, y la de Rimbaud -con el poema "Génie» en particular ${ }^{28}$. En la cumbre de una intensidad eufórica, Trakl canta, en la línea de «Helian», la transformación musical del dolor, cuando la dimensión órfica lleva al solitario a la iluminación nocturna, cuando el adentramiento en la noche de la vida psíquica profunda conlleva la armonía con la naturaleza.

De hecho, como lo analiza Michèle Finck, en una lectura vertical del poema alemán se destacan cuatro pilares: armonía, amor, casa y medida. Armonía y amor son las claves de una casa musical cerrada sobre sí misma, entre «los verdes bosques» liminares y «las leyendas del bosque» finales. Incluso la casi repetición de la palabra del título, "Abgeschiedenen», cierra el poema alemán, en plural ahora. Con Antonio Gamoneda, se hace manifiesto el acto de fe trakleano en la difícil hermandad del canto, por el paso del singular del título, "solitario», a la explicitación en plural, "de quienes se retiran a las cercanías de la muerte». Por esta interpretación, desde las ocultas bóvedas de la canción, se firma la reescritura del dolor, de la muerte y de la compañía. Desde su propio "espesor dotado de melancolía», el sujeto gamonediano - «escultor de sombras» que "hunde sus manos en el silencio» (Descripción de la mentira, 220, Lápidas, 247)-, por el mismo poder de su escritura, va a revelar el último sentido del canto trakleano.

27. Véase el artículo decisivo de Miguel Casado sobre "La canción de la ira», Quimera, op. cit., p. 34-45.

28. Rimbaud, "Génie», Illuminations, Poésies, CEuvres complètes, ed. y pres. Antoine Adam, París, NRF Gallimard, Bibliothèque de la Pléiade, 1972, p. 154-155. 
Antonio Gamoneda suele oponer dos categorías de lenguaje, «categoría de informativo" y "categoría de subversivo». Respecto a la escritura, se oponen el «acto de información, de explicación», y el «acto subversivo» ${ }^{29}$. La idea de «imitación profunda» llevó a Antonio y Amelia Gamoneda a perseguir «la sustancia semántica y poética más allá de las correspondencias léxicas y sintácticas» en su versión de Herodías de Mallarmé. Así se ilumina el rechazo de lo informativo que expresan las líneas de la carta ya citada: «echaba de menos en [las versiones contempladas] la condición de poema. Me resultaban únicamente informativas.» Entonces ¿cómo identificar aquella condición de poema en la reescritura de las dos mudanzas?

La versión original, "Gesang des Abgeschiedenen», tal y como aparece en la edición bilingüe de Américo Ferrari, leída por Antonio Gamoneda, se compone de seis estrofas (de 4/2/4/3/3/2 versos). Como las versiones francesas, las tres versiones españolas aludidas nos informan sobre la disposición original reproduciéndola. En cambio, el espejo gamonediano fracasa como mero reflejo, prefiriendo la imprevisibilidad del sonoro fluir de quince fraseos en los que se redistribuyen las estrofas. Podríamos decir con José Ángel Valente que se da un nuevo "conocimiento presentacional» ${ }^{30}$. Los blancos invaden la página -y con los blancos musicales, canta el silencio. El encabalgamiento fuerte entre la primera y la segunda estrofas del original deja ésta en suspensión en el viento (entre «melodiosas en el viento,/vienen también...»). La creación refuerza la suspensión a su manera. Se destacan los versos del bloque estrófico alemán en un movimiento de distinto reparto, hasta la esperada unificación en el tercer fraseo de la reescritura: se ofrece entonces la manifestación material del avance de las «húmedas sombras» y de las «flores del verano». En tales «bloques rítmicos»" ${ }^{31}$, cuyas pausas visuales permiten la respiración, late un aliento: el que a partir de Descripción de la mentira, viviendo ya del «líquido de los sueños» de Lápidas (266), da paso al

29. $H P R$, art. cit., p. 89 o El lugar de la reunión, art. cit., p. 142-143 y Antonio y Amelia Gamoneda, «Avisos y preámbulos», Mallarmé Herodías, Madrid, Abada, 2006, p. 12. Pienso en lo que escribe Yves Bonnefoy a propósito de su traducción de Yeats: «Et c'est évidemment cet élan, cette fougue de l'esprit à rebâtir ce que l'esprit brise, à être parole malgré les mots, qu'il faut que le traducteur de Yeats recommence ou du moins essaie de revivre [...].» (Yves Bonnefoy, "Introduction», Quarante-cinq poèmes de Yeats suivis de La Résurrection, París, Hermann, 1989, p. 24.)

30. José Ángel Valente insiste en la importancia de la recepción inmediata del poema o del cuadro, cuando en un instante se recibe su belleza aún sin descifrar, la «revelación fundamental». («El ángel de la creación», entrevista a José Ángel Valente por Ana Nuño, Quimera, no 168 , abril 1998, p. 12.)

31. La expresión es de Antonio Gamoneda, en "Poesía en la perspectiva de la muerte», El cuerpo de los simbolos, op. cit., p. 29. 
fraseo de bloques simétricos que en seguida reconoce el lector. En su pausado oleaje, la nueva configuración estrófica de "Canción del solitario" se hace tensión espacial reconciliadora, hasta la reunión de los hermanos peregrinos en los "caminos lunares». Cada fraseo tiene un promedio de más de veinte sílabas, y se desarrolla con la lentitud de los sueños, al mismo compás que el rallentando característico del ritmo sospechado de Trakl. Como en el poema original, el único dinamismo se halla al principio. A partir de la segunda frase, la extensión sonora y visual de «las praderas cristalinas» sosiega el ímpetu del fraseo liminar, imponiendo hasta el final un legato típicamente trakleano, encontrado/inventado en extraña afinidad imaginaria y vocal, por encima de todas las lejanías: "Y levantar con lentitud sagrada/mi corazón entonces...» (Sublevación inmóvil, 55). Tal es la otra expresión del crecimiento musical de la melancolía, aún preso en la segunda estrofa trakleana, ahora liberado por la extensión del cuarto fraseo en el centro del poema, como su centro vital: "Anochece en la frente del hombre pensativo..."

Por otra parte, Gamoneda descarta las abstractas «aves» de las tres traducciones españolas, prefiriéndoles "pájaros» que parecen surgir de la realidad, la del otro poema inalcanzable, la de la vida, o la de la obra, donde desde el «bosque secreto» o la «selva roja» de Exentos II, «un pájaro revuelve la espesura/y, luego, lento, en el azul se eleva/y el canto lo sostiene y pacifica» $(149,147)$. En la otra punta de la onda sonora, "Cargado de armonía está el vuelo de los pájaros.» El participio «cargado» funciona como el la del diapasón de la reescritura, en vez del adjetivo «lleno» de las demás versiones. Traduce el peso de la palabra "armonía», en plural en el texto alemán. ¿Un conjuro del "pájaro verdugo" de la memoria en Arden las pérdidas (467)? Con tal ataque se impone tanto rítmica como léxicamente el peso grave del fraseo gamonediano, en la tensa oscuridad del mundo lento de sus imágenes. Los ejemplos en la obra serían muchos. Una «lentitud sagrada», una "silenciosa carga», el deseo de una música que suene «a tensa oscuridad, a mundo lento", reinan desde Sublevación inmóvil $(55,56,59)$. La sensación física se repercute a lo largo de Descripción de la mentira: "Mi cuerpo pesa en la serenidad y mi fortaleza está en recordar», "el corazón pesa en obras agotadas» $(179,217)$. Sigue imponiéndose en Libro del frío: «pesan las flores sobre praderas atormentadas por la lluvia», «tú pesas en mi corazón» (311, 363). En Arden las pérdidas, el cuerpo sufre de modo aún más agudo el agobio de siempre: pesan "las piedras en mis ojos», y hasta las canciones pesan, igual que los recuerdos, "coágulos de sombra» $(423,475,424)$. "Lourdeurs existentielles», semejantes a las que expresa la obra de Trakl ${ }^{32}$. Pero tal

32. Rémy Colombat, Rimbaud-Heym-Trakl, op. cit., p. 502. 
carga, ahora resuelta en armonía en el espejo distanciador de la reescritura, lanza pues el movimiento de la canción. El desliz sonoro de «Canción» a «Cargado» es obvio, y desencadena la extensión mágica de los ecos: «vuelo de los «pájaros» por las "praderas cristalinas de los ciervos», que fónicamente se prolongan a su vez hasta los «verdes bosques». La voz conduce el halo sonoro hasta un presente de eternidad: «se reúnen». Cabe notar tal elección, cuando las otras lecturas sitúan el relato lírico en un pretérito perfecto. Unas rimas internas en e-o se responden (vuelo, ciervos), invertidas en o-e (bosque), con diseminadas notas acentuadas, que reactualizan el ámbito sonoro del principio: en la «sintaxis para la sensibilidad» ${ }^{33}$, «silencio»y «sosiego» rodean y amparan al «enfermo».

La reescritura gamonediana coincide -en particular sobre la expresión poética de la reunión - con las elecciones anafóricas de la lectura francesa posterior de Michèle Finck, de 2004, sin la menor duda la más musical de todas las traducciones francesas ${ }^{34}$. La letanía gamonediana le confiere al poema su ritmo lento pero avasallador mediante las anáforas que junto con los blancos, reinventan el poderoso avance con rallentando de Trakl: «Vienen húmedas sombras... vienen también las flores del verano.» "Ésta es... así son...»El lector recuerda Primeros poemas - Viene la noche...» (26)- y sobre todo Descripción de la mentira o Lápidas, donde la visión emerge en parte gracias a la misma expresión de afluencia móvil de las imágenes hacia el yo que las recoge: «Vienen rostros...» (173), «Vienen dibujando cúpulas...», "viene apartando ramas...» $(272,299)$. La fórmula se impone en el título del primer movimiento de Arden las pérdidas, "Viene el olvido», cuyo ataque es tan intenso que lanza el movimiento hasta «Ira», segunda parte dinamizada en sus cuatro primeros poemas por la misma recurrencia hipnótica: «viene/ esta pena arterial», "Hasta los signos vienen/las sombras torturadas», "¿Quién viene...», «Vienen con lámparas, ...» (435-438). Alterna con el verbo ver en pretérito o presente, otro instrumento que desencadena la serie de imágenes visionarias, como en "Le Bateau ivre» o en Poeta en Nueva York. Con una diferencia fundamental respecto a Rimbaud -sólo la sugiero de momento-, pues la dinámica del salto, propia de la escritura de Rimbaud, equivaldría en términos musicales a la de la nota picada, mientras que la (re)escritura

\section{Ibid., p. 24.}

34. En la carta a la que ya aludí, Antonio Gamoneda evoca su "continuo asentimiento» tras su lectura ulterior de otras traducciones de Sébastien en rêve por Michèle Finck (Polyphonies, n 8, invierno 1988-89, p. 35-39). En «Chant de l'Isolé», Michèle Finck traduce los versos que cito al final del párrafo por «Avec amour aussi le silence enlace dans la chambre l'ombre de l'ancêtre... Et l'enlacent, avec violence, la bleuité fraîche et la chute étincelante de l'automne...» (op. cit.). 
musical de Antonio Gamoneda, igual que la de Trakl, expresa la energía de la nota tenida: «Alguien silba en mi corazón. No sé quién es pero entiendo su sílaba interminable.» (Arden las pérdidas, 462) Concreción lancinante, en el octavo fraseo de la "Canción del solitario", el empleo del verbo "rodear» -«En las habitaciones, el silencio rodea con amor las sombras de los antepasados»-, reiterado más abajo, "y le rodean la frescura azul, el luminoso final del otońo", manifiesta la estructura circular trakleana, en un poema de reconciliación del yo consigo, en la armonía del mundo y la armonía interior más profunda: la expresión de una "poderosa ritmación redonda" (Exentos II, 158).

$\mathrm{Al}$ "paciente» de las versiones "informativas», sustituye el "enfermo" de la canción, el que "despierta de los negros instantes de la locura», como si surgiera de la sombra del «laurel enfermo» que se extiende por la obra (Arden las pérdidas, 475). La canción es la luna de una escritura acosada por las visiones de las «antiguas celdas» de la memoria, entre tumba y "jardín torturado», con "la edad del hierro en la garganta» $(413,461,472)$. Por eso desde el poder de la reescritura, cercanía y distancia, se levanta un conjuro memorial, igual que en el relato de la otra mudanza - Se acordaba de su infancia cargada de enfermedad y de tinieblas»-. En vez de un espejo «riguroso», brota por necesidad interior un espejo musical resolutivo, tanto para la mudanza como para su autor, gracias al trabajo de ahondamiento y de proyección hacia fuera de las imágenes más obsesivas, en el misterio del encuentro imposible -o precisamente por la energía interior que engendra la imposibilidad. Así, en la "subversión» reveladora, la "lamparita» exterior desaparece, hacia un movimiento de plena interiorización de la luz: «y una llama de bondad arde en su corazón». En la canción, estas palabras se funden con el principio del cuarto fraseo, «ya anochece en la frente del hombre silencioso", rechazando la escisión estrófica trakleana: «condición de poema», donde se redistribuyen las unidades de respiración trakleana hacia su propia revelación en la simpatía, «en posesión recíproca», como lo escribe Antonio Gamoneda a propósito de su relación con los spirituals ${ }^{35}$. La razón musical llega a imponer la elección del silencio. "Cabañas silenciosas» y no «tranquilas» (la palabra alemana "still», tres veces repetida, designa a la vez la paz y el silencio). En cambio, en la sintaxis respirada progresa poco a poco el silencio, y se gana al final de la canción "el sosiego de la casa», que ya no tiene que ser explícitamente «casa silente», como en Palazón.

35. Antonio Gamoneda, «Sobre Nazim Hikmat, los negro spirituals y mi Blues castellano», El cuerpo de los simbolos, op. cit., p. 91. Como lo dice Yves Bonnefoy, «Rien de pire [...] que ces phrases qui laissent la sympathie sur sa faim, mieux vaut l'interprétation erronée que cette glu du vague où ne s'élabore aucune forme vivante.» (op. cit., p. 27-28.) 
Contrariamente a las tres versiones contempladas, Antonio Gamoneda aumenta la escasa presencia de puntuación en Trakl, ańadiendo a la canción dos puntos y cuatro comas. Pero paradójicamente, ésos no detienen el avance de la amplia respiración, sino que son como los signos musicales que en una partitura señalan pausas o silencios en el movimiento. Funciona de igual manera la supresión de la coma en el fraseo central, "Ah vivir en el azul y el espíritu de la noche.» "Oh, ...», dicen las otras versiones, que eligen la nota picada en vez de la nota tenida gamonediana. Expresión de una respiración honda, la nota tenida abre la línea melódica extensa de la restauración sonora.

Hacia la arquitectura de la armonía y del amor, edificación de la casa musical, la cuarta piedra trakleana es la «medida», convocada en la sexta y última estrofa, de dos versos. Desestabilizando la estructura estrófica para llevar a cabo su rallentando final, Antonio Gamoneda extiende entre blancos cinco versos aislados, y puntúa fuertemente tras «leyendas del bosque», antes del respiro interior final, «Esta es la medida y la costumbre, así son los caminos lunares/». Ya no la «norma» sino la "costumbre», la expresión revivida del caminar trakleano hacia una involución feliz, en la armonía órfica nocturna. Baile inmóvil pero con latido profundo, la coreografía aérea de las líneas gamonedianas dice el encuentro intuitivo con la voz de Trakl, con su verso encorvado sobre sí mismo, donde todo suena y repercute el sonido vocálico. Desde la conquistada paz interior, en el colofón se puede poner en plural la palabra del título, ensanchando el proyecto armónico. Se ofrece un espacio final hospitalario para otras sombras hermanas, posadas ahora en el «umbral de piedra», ya acabado el camino por todos los quebrantos del cuerpo y del alma, en la "Arcadia sonora" ${ }^{36}$ del canto.

En el enigma de tal convergencia hacia la voz de Trakl, desde la «rítmica de las ideas» que funda la poética gamonediana ${ }^{37}$, la música no es sólo símbolo de salvación, sino fuerza de salvación, por el sosiego y la transfiguración que implica. Los «verdes bosques», igual que los "pájaros», designan la vida, en su realidad más sencilla, entrevista tras el cristal de las praderas, de brillo irreal, fronterizo con el sueño: otra más alta vida, que nos deja-como lo dice Antonio Gamoneda sobre los límites entre los géneros-, «con las fronteras desamparadas». Por cierto, siempre acechan los "caminos espinosos», «los martirios purpúreos, el lamento de una estirpe» ${ }^{38}$. Pero Gamoneda subvierte

36. La expresión es de Michèle Finck, op. cit., p. 97.

37. Me refiero por ejemplo a la idea esencial de «acomodación rítmica del pensamiento a la causa musical desencadenante» (Antonio Gamoneda, HPR, art. cit., p. 84 o en El lugar de la reunión, art. cit., p. 138).

38. En el mundo de imágenes de Trakl, donde el poema construye la continuidad poética 
la elección de la «queja» por Ángel Sánchez y José Luis Reina Palazón, sustituyéndola como Américo Ferrari, por la poética del «lamento»-si no solución, ya resolución musical ${ }^{39}$.

\section{LAS «CACERÍAS SECRETAS» DEL POEMA («SUEÑO Y LOCURA» [FRAGMENTOS])}

El segundo panel del díptico musical ofrece un nuevo acto de fe en la escritura poética como revelación ${ }^{40}$. Antonio Gamoneda elige el principio del segundo de los tres bosquejos autobiográficos en prosa que rematan Sebastián en sueño, "Traum und Umnachtung». Para Jenaro Talens, los poemas de Trakl son «fragmentos que contienen cada uno de ellos la totalidad de los demás» ${ }^{41}$. ¿QQué sentido otorgarle a la doble fragmentación, central y final, impuesta por Gamoneda al relato de la obsesión por la experiencia del mal y de la culpa, desde el mundo de la infancia?

Igual que Ángel Sánchez, Antonio Gamoneda interpreta «Umnachtung» por «locura»-cuando José Luis Reina Palazón traduce por «entenebrecimiento», y Américo Ferrari «delirio». La palabra para Trakl no tiene sentido negativo clínico, sino que dice el destino del que ve, el sueño del que se hunde en las tinieblas para encontrar la mayor claridad. Ahora bien, desde Exentos I, late soterrada la «soledad que enloquece y despoja» las «láminas

pasando de imagen a imagen, importan tanto los espinos negros, punto fijo en la fluidez musical, como la púrpura, color de las heridas mortales, que anuncia la muerte, pura señal de la nada que llega con lo negro (cf. Robert Rovini, La fonction poétique de l'image dans l'œuvre de Georg Trakl, París, «Les Belles Lettres», 1971, p. 101-134).

39. A propósito del planto gamonediano, que a partir de Descripción de la mentira, hasta surge impersonal por la fuerza igualitaria de la muerte, Clara Janés insiste en la «objetividad del lamento", que "permite a Gamoneda incluso contemplar la belleza en el horror» ("Antonio Gamoneda: de vértigo y olvido», Revista de Occidente, Premio Cervantes 2006, abril 2007, $\mathrm{n}^{\circ} 311$, p. 68).

40. Pienso en el texto de Gamoneda titulado «Las lágrimas de Claudio» (Archipiélago, Cuadernos de crítica de la cultura, «Claudio Rodríguez. Pulso y revelación del verso», n 63, p. 22).

41. Jenaro Talens, «Introducción», Stadler-Heym-Trakl, Poesía expresionista alemana, trad. Jenaro Talens y Ernst-Edmund Keil, Madrid, Hiperión, 1981, p. 21-22. La reciente publicación de Sebastián en sueños y otros poemas en una traducción de Jenaro Talens (Barcelona, Galaxia Gutenberg/Círculo de Lectores, 2006) recalca la actualidad de la «oscura armonía» de la voz trakleana, según las dos palabras de "Canción del atardecer», citadas de modo emblemático por Juan Eduardo Cirlot («La poesía de Georg Trakl», Cuadernos Hispanoamericanos, 253254, enero-feb. 1971, p. 247). Gracias a Yves Germain, menciono las traducciones de J. L. Castillo, «Homenaje a Juan Cirlot: E. A. Poe \& Georg Trakl», Revista órfica Nigredo, París, $\mathrm{n}^{\circ} 2,2005,56-60$. 
abrasadas» del sueño $(87,49)$. ¿Cómo no recordar la lucidez desgarradora, definitiva, del octavo poema de Arden las pérdidas, "Así/enloquezco en la verdad» (420)? Constelación próxima a las que inquietan tanto en Trakl -apariciones y sangre, muertos y gritos entre azul y negro, la mayor oposición de colores, que caracteriza todos los poemas de Trakl-, en Descripción de la mentira ya forman grumo en la memoria la lentitud, la enajenación del yo ("el animal que sangra dulcemente dentro de mi alma») y la locura, que "crece en este resplendor». La memoria gamonediana, «recamada de espejos», vive en un "país sin retorno", y la voz sabe los tormentos anteriores al sosiego en el «umbral de piedra»: «Yo, en los manjares previos a la muerte, hallo mi lucidez», «Estoy naciendo del cansancio» $(179,183,184,187)$. Suenan las palabras ya citadas: «las leídas versiones "informativas" me hacían sospechar un texto poemático original del cual, sí, yo me adivinaba cercano.» Según lo analizó Miguel Casado ${ }^{42}$, el canto gamonediano de la retracción surge de las imágenes traumáticas de la infancia, impresas para siempre en la córnea del niño de León (473): «Aprendí a aullar mientras se rompían vidrios dentro de mis ojos.» (Arden las pérdidas, 468). El vínculo queda explícitamente anudado en Descripción de la mentira: "Cesa el fermento de mi infancia: cesa el horror y su oquedad es grande.» (211) Fuente de las visiones del drama interior, de la infancia queda una oscura resonancia que no se apaga: «el sonido de mi infancia/las huellas de mis ojos, los contenidos de mi alma» (209).

Es evidente la afinidad con el relato en que Trakl se mira y mira su obra como en un espejo, en una trasposición mítica de la infancia. «Al anochecer el padre se convertía en un anciano [...]»: nota tenida el imperfecto, que sólo aparece en Ferrari, reflejo de un tiempo lento. Así surge el cruce de las cuatro figuras paternas, con una inversión, pues Antonio Gamoneda perdió a su padre, poeta, cuando tenía un año: "Vivo sin padre y sin especie...» (Exentos II, 145), «He gastado mi juventud ante una tumba vacía...» (Arden las pérdidas, 461). Parece prolongarse el tiempo de la «relación» final de Arden las pérdidas, el de «la infancia rodeada de vértigo», cuando «Dormía ante los espejos» (473). En su deseo manifiesto de fragmentación, la reescritura se va haciendo más posesiva, reviviendo en el nuevo fragmento la totalidad de sus obsesiones.

Pues los dos cortes no sólo indican una ruptura. Permiten la intensificación del recuerdo total de una vida, desde el reflejo en la otra escritura, donde se

42. Miguel Casado, «Epílogo», Esta luz, op. cit., p. 611. Véase también id., «Un ejercicio de comparación: Lapidario y Lápidas», en Antonio Gamoneda, Madrid, Calambur, col. Los solitarios y sus amigos, 1993, p. 122. 
crea la posibilidad del reconocimiento reflexivo y del sosiego, que amplían la armonía de la canción. Con los primeros corchetes, se elimina lo que no tendrá nunca sitio sosegado en la memoria. Cito en la traducción de Américo Ferrari (leída por Antonio Gamoneda) el texto mudado, dejado fuera del umbral de la reescritura: «A la puerta del convento mendigaba un mendrugo; la sombra de un caballo negro saltaba de la oscuridad y lo espantaba. Yacía en su frío lecho y lo acometía un llanto indescriptible [...]». Es insufrible el recuerdo de la agonía del otro caballo, aquella visión atroz que perfora la memoria, desde Descripción de la mentira, con "los caballos que agonizan en campamentos muy lejanos» (208), hasta Arden las pérdidas, "Hay un caballo dentro de mis ojos y es el padre de los que aprendieron a llorar.» (467) Liberada, la (re)escritura se entrega al poder armonioso de su sueño, hacia el descubrimiento de las propias "cortinas blancas», más allá de las imágenes. Se reactualiza la visión de Libro del frio, «He atravesado las cortinas blancas:/ ya sólo hay luz dentro de mis ojos.» (407) Se hace bloque unitario el nuevo conjunto. Después de entrever a los cadáveres con «las manchas verdes de la descomposición en la belleza de las manos» (recordamos que la visión de las manos es obsesiva en Esta luz), la escritura se instala exactamente en el "umbral del piedra» de la canción, después de la locura y la enfermedad. A las «leyendas del bosque» del canto de la reconciliación, cuando la voz pone sordina a las «leyendas de las cintas fúnebres» que atormentan la escritura (Arden las pérdidas, 463), responde claramente «la leyenda de la fuente azul». Fuera del nuevo bloque, en el resto del relato, el azul trakleano queda vencido por las oscuras fuerzas del mal y de la culpa. Pero el yo gamonediano pesa con su gravedad física propia contra tal renuncia a la armonía musical. La reescritura crea en ese momento cuerdas con esperanza -las que no pudo conocer el vigilante de la nieve ${ }^{43}$, "el cantor de las heridas», con sus "cańas negras» (Libro del frío, 329).

En vez de dejar paso a la inarmonía, ineluctable desembocadura para Trakl, «Sueño y locura» dice en su fragmentación reconciliadora una plenitud sosegada, inscrita en el cuerpo y el alma. La escritura de Cecilia no está lejos: «Todo es visión, todo está libre de sentido.» (496) «Irremediablemente subjetiva» la poesía. En vez del «muchacho»o «niño» de las tres traducciones, la subversión más profundamente fiel introduce un pronombre personal, que permite la proyección del sujeto de la escritura en el centro del relato: «sentía que sobre él... Se acordaba... se acordaba...»El arranque lírico del personaje

43. La multiplicación especular de la voz gamonediana la lleva a asimilarse en la obra con ese canto que es el de las «sílabas negras» (Arden las pérdidas, 471). Se impone el recuerdo de la última frase de El cuerpo de los símbolos, al final de «El vigilante de la nieve»: «quizá alguna vez yo he sido o voy a ser el vigilante de la nieve.» (op. cit., p. 233.) 
hacia la figura desaparecida - «Creo en la desaparición.» (Arden las pérdidas, 432) - es tan fundamental desde la poética gamonediana que se escamotea el participio «muerto», que sólo remite a una imaginería romántica: «Y él se precipitaba [muerto] en las sombras.» Se impone entonces la invasión del silencio, y la reescritura le añade un adjetivo al dolor: «silencioso». Hasta surgen coloraturas nuevas con la visión gamonediana, reforzando el juego trakleano de los colores, quizá lo más hondo y secreto de su poesía: «la campiña dorada», «la tarde roja», «la canción del junco amarillo» (en vez de amarillento, que apaga el canto de las imágenes, destruyendo la intensidad trakleana de los colores $\left.{ }^{44}\right)$. Las otras versiones, en la línea del cristianismo musical de Trakl, mantienen la huella mental de la piedad o devoción (es la «ardiente devoción» de Ángel Sánchez). Con Gamoneda en cambio, se crea una intensificación de las sensaciones corpóreas del personaje-sujeto: "La piel ardía.» Por fin, tres fraseos, de igual índole que en la canción, más allá de la diferencia entre fraseo versal y lírica en bloque, amplían la anterior exclamación extática, "Ah vivir en el azul...», "Ah las horas de éxtasis salvaje...», "Ah el alma cantando suavemente...». Como las demás, la última exclamación es puro fraseo versal, "Ah los peces plateados y los frutos desprendidos de árboles sarmentosos». El participio «desprendidos» reescribe la imagen final de la caída, tan trakleana, sustituyéndola por la suspensión eterna y luminosa de cada fruto - palabra o poema-, potenciada por el segundo corte indicado por los corchetes, o mejor dicho por el colofón que la prolonga infinitamente. Desprendida de sus visiones, tan suyas como ajenas, la voz alcanzó su casa musical, y es música.

Para conjurar la visión de las verdes manchas de la muerte, sólo se podían convocar otras imágenes más fuertes: «la tarde roja en el verdor del río, las cacerías secretas.» "Cacerías secretas», un adjetivo extraño en todos los sentidos de la palabra. De hecho, si no aparece en las traducciones españolas ni francesas, es que tampoco pertenece al texto de origen. Una nota menos añadida que extraña al bloque poético, como lo dicen los músicos a propósito de una nota extraña al acorde ${ }^{45}$. Nota escapada, o elisión, esencialmente melódica, que escapa de la nota que precede, y anticipa un paso hacia el acorde siguiente. Al final, una manifestación de la palpitación rítmica de

44. Sobre la complejidad del juego de los colores en Trakl, entre intuitivo y simbólico, con contrastes brutales, cf. Jean-Michel Palmier, Situation de Georg Trakl, París, Belfond, 1972, p. 205-246.

45. Al armonizar una melodía o realizar una composición, los músicos suelen encontrar sonidos que no pertenecen al acorde, pero que enriquecen el movimiento melódico de las voces. Son las notas extrañas, siendo la escapada o elisión una de sus modalidades. Mi agradecimiento a Marie, a Azucena López Cobo y a Hélène Pardo por su ayuda técnica. 
la presencia trakleana, más oída que escuchada, que lleva la reescritura gamonediana a descubrirse como escritura del sosiego y del éxtasis musical: "Ah el alma cantando suavemente la canción del junco amarillo.»

"Hablas/suavemente en mis labios y regresas/a tu prisión de melancolía.» (Libro del frío, 365) En el callado diálogo de las dos mudanzas con un tú inalcanzable - ¿¡Y tú te ocultas, el habitante de mi alma?» (Descripción de la mentira, 215) ${ }^{46}$, se crea una armonización profunda, sin que asome el inquietante coro de voces de los poemarios. En Trakl, el cazador sangriento habita en el bosque de los poemas del mal. En sus cacerías secretas, la voz gamonediana le ofrece una mudanza, donde se revela la virtud musical de la melancolía. "Ah, como un monte, la melancolía crece en los pastos invernales», dice la voz de Lápidas (277). La coma aún detiene la respiración. Reinan los pastos invernales, con sus «símbolos negros» (284). Mas en el último armario de dos lunas - "posibilidad de cercanía y comprensión»-, la memoria del propio bosque respira exenta. En los brillos de las ajenas "praderas cristalinas», se concentran las revelaciones de las "verdades cóncavas» (284) de la escritura, como si se pudiera olvidar el sentido desesperado de la canción del Libro del frío: "No vale nada la vida,/la vida no vale nada.» (375) Y desde las habitaciones oscuras de las mudanzas, se oye la «melancolía generosa» de Antonio Gamoneda, según la expresión de Fernando R. de la Flor ${ }^{47}$. La "Canción del solitario" abre sus "caminos lunares» a cuantos quieran encaminarse por ellos, hacia el pan y el vino que revela la escritura.

Cuando evocaba la obra de Edmond Jabès, José Ángel Valente aludía a su «influencia retrospectiva», explicando que su lectura o su relectura le permitía «ver de otra manera determinados aspectos de su propia obra -o verlos, incluso, por primera vez, considerados a la luz de la peculiar simbología jabesiana.» ${ }^{48}$ Gracias al colofón trakleano de Esta luz, el lector oye vibrar unas resonancias que se reúnen con cincuenta y siete años de escritura poética: una vibración final, feliz, la huella sonora del paso de una

\footnotetext{
46. Eso dice de otra manera Antonio Gamoneda a Luis Algorri: «uno mismo es también los otros.» La voz de un poeta es «una voz patrimonial, una voz que algo tiene de colectivo, de múltiple. Lo que ocurre es que se produce [...] una especie de interiorización dramática de esos otros que funcionan en uno. Es una pelea.» Luis Algorri, "Antonio Gamoneda, entre el tú y el usted», "Filandón», Especial dedicado a Antonio Gamoneda, Diario de León, 10/7/1988, p. 27. Sobre la frecuente «simultaneidad de las voces» que impide la armonización, en particular en Descripción de la mentira, pero creo que a lo largo de la obra, cf. Ildefonso Rodríguez, art. cit., p. 41.

47. Fernando R. de la Flor, op. cit., p. 38.

48. Citado en "Introducción», José Ángel Valente, Obras completas I, Poesía y prosa, ed. e introducción Andrés Sánchez Robayna, Barcelona, Galaxia Gutenberg/Círculo de Lectores, 2006, p. 52.
} 
fuerza poderosamente unitaria. Es ritmo aquella fuerza, por la que escritura y reescritura se contestan y se mezclan. Por decirlo con palabras de Yves Bonnefoy, ese ritmo se sitúa en el nivel más profundo, «celui où paraît une force qui est, dans l'esprit et même le corps, quelque chose de plus que les désirs ordinaires.» ${ }^{49}$ Aparece cuando se levanta desde lo hondo del poema «la sorte de continuité, d'épaisseur qui est dans les poèmes qui valent.» Así, desde el legato de la "Canción del solitario" y de "Sueño y locura», se alza como firma de Esta luz un rostro inventado en la armonía, que ofrece a la voz poética una identidad musical que estaba dentro de la obra, y emerge, reconciliada consigo misma, en el espejo del otro solitario. 


\section{BULLETIN HISPANIQUE}

\section{Canción del solitario}

Cargado de armonía está el vuelo de los pájaros. En las praderas cristalinas de los ciervos, los verdes bosques se reúnen al atardecer en torno a cabañas silenciosas.

La oscuridad hace más tenue el murmullo de las aguas. Vienen húmedas sombras

y, melodiosas en el viento, vienen también las flores del verano.

Ya anochece en la frente del hombre pensativo y una llama de bondad arde en su corazón.

Es la paz de la cena: el pan y el vino están benditos por las manos de Dios

y, en silencio, con sus ojos nocturnos, tu hermano te mira y descansa de los caminos espinosos.

Ah vivir en el azul y en el espiritu de la noche.

En las habitaciones, el silencio rodea con amor las sombras de los antepasados,

los martirios purpúreos, el lamento de una estirpe

que, piadosa, se extingue en el descendiente solitario.

En el umbral de piedra el enfermo despierta de los negros instantes de la locura

y le rodean la frescura azul, el luminoso final del otoño,

el sosiego de la casa y las leyendas del bosque.

Esta es la medida y la costumbre, asi son los caminos lunares

de quienes se retiran a las cercanias de la muerte. 
Sueño y locura *

[Fragmentos]

Al anochecer, su padre se convertía en un anciano; en las oscuras habitaciones se petrificaba el rostro de su madre y sentía que sobre él pesaba la maldición de una estirpe. Se acordaba de su infancia cargada de enfermedad y de tinieblas; se acordaba de los juegos sigilosos en el jardin, bajo las estrellas, y de cuando alimentaba a las ratas en el patio invadido por el crepúsculo. De un espejo azul salia la delgada figura de la hermana y él se precipitaba en las sombras. En la noche, su boca se abría como una fruta roja y las estrellas derramaban luz sobre su dolor silencioso. La vieja casa de los padres se llenaba con sus sueños. Le gustaba cruzar el cementerio en ruinas, contemplar los cadáveres depositados bajo bóvedas y las verdes manchas de la descomposición en la belleza de las manos. [...] Al llegar el otoño, se adentraba cargado de visiones en la campiña dorada. Ah las horas de éxtasis salvaje, la tarde roja en el verdor del rio, las cacerias secretas. Ah el alma cantando suavemente la canción del junco amarillo. La piel ardia. Miraba los ojos estelares de los sapos, palpaba con manos temblorosas la frialdad de las piedras y consideraba la leyenda de la fuente azul. Ah los peces plateados y los frutos desprendidos de árboles sarmentosos. [...]

Antonio Gamoneda

Trakl, Mudanzas [2003]

* Con la autorización de Antonio Gamoneda, el Bulletin Hispanique publica agradecido las dos mudanzas de Trakl incluidas en Esta luz Poesía reunida (Poesía 1947-2004), epílogo de Miguel Casado, Barcelona, Galaxia Gutenberg/Círculo de lectores, 2004, p. 569-572. 
